\title{
Editorial \\ Introduction to Special Issue: Organ Transplantation in Islam: Perspectives and Challenges
}

Jan A. Ali

Citation: Ali, Jan A.. 2022. Introduction to Special Issue: Organ Transplantation in Islam: Perspectives and Challenges. Religions 13: 200. https:// doi.org/10.3390/rel13030200

Received: 11 January 2022 Accepted: 10 February 2022 Published: 25 February 2022

Publisher's Note: MDPI stays neutral with regard to jurisdictional claims in published maps and institutional affiliations.

Copyright: (C) 2022 by the author. Licensee MDPI, Basel, Switzerland. This article is an open access article distributed under the terms and conditions of the Creative Commons Attribution (CC BY) license (https:// creativecommons.org/licenses/by/ $4.0 /)$.
School of Humanities and Communication Arts, Western Sydney University, Penrith, NSW 2751, Australia; jan.ali@westernsydney.edu.au

It has been suggested that tissue and organ transplantation, as a surgical procedure to restore lost or mutilated body parts, is a centuries-old practice confirmed in an ancient Sanskrit text on medicine and surgery called the Sushruta Samhita in circa 600 B.C (Schlich 2010). Ancient Egyptian, Greek, Roman, and North and South American surgeons transplanted teeth and Arab medical practitioners mastered this technique over a millennium ago (Peer 1955; Kee 1986). Hamilton (2012) found in his study that various images of the third-century twin physician saints Damian and Cosmas in several shrines reveal them transplanting a human limb. Although the concept is not new, the way complex medical surgical procedures are carried out and the types of organ transplantations practised such as heart transplantations today are new modern medical marvels achievable due to the progress made in medicine, science, and technology.

From the early to mid-twentieth century the skin and "monkey gland" transplantation, the growing of organs from stem cells in laboratories, and the successful grafting of an organ from person (donor) to person (recipient) (Hamilton 2012) revealed the true marvel of modern medicine and put a new spotlight on surgeons (Seghers and Longacre 1964). Towards the end of the twentieth century, the clinical success of organ transplantation between humans was resounding, reaching the status of a routine and normal procedure.

Organ transplantation or organogenesis as it is known in medical and biological sciences is a treatment for otherwise fatal end-stage organ failure. It is a medical procedure involving the movement of a piece of tissue, or a part of an organ, or a whole organ from one location in the body to another (autotransplantation), from one body to another (allograft or allotransplantation), or from an animal body to a human body (xenograft or xenotransplantation). Allotransplantation is the most common type of transplantation procedure applied to the most common treatment of end-stage kidney, liver, lung, and heart diseases. Human kidneys are the most commonly transplanted organs globally followed by the liver and the heart. Organ or tissue transplantation is seen as a disease-cure source and an effective lifesaving procedure; therefore, the objective is to provide the recipient facing imminent death with a functional replacement, offering him or her the opportunity for an improved and enduring quality of life. Today, numerous vital organs and intricate tissues can be successfully transplanted including the kidney, liver, heart, lung, skin, pancreas (e.g., the islets of langerhans), intestine, bone, cornea, middle ear, bone marrow, heart valves, and connective tissue (Al-Bar and Chamsi-Pasha 2015).

However, the practice of tissue and organ donation and transplantation has always attracted intense ethico-moral and legal debates. These debates are nowhere as intense as is in Islam. Tissue and organ donation and transplantation are not specifically discussed in the Islamic scriptures, namely the Qur'an and hadiths (records of the traditions and sayings of the Prophet Muhammad). In fact, these two great texts of Islam are silent on the matter. For centuries this was not a subject of much philosophical, intellectual, and theological interest and discussion in Islam and has only become a concerning matter in the last fifty years with the clinical success of organ transplantation between humans becoming an 
established medical procedure. Many Muslims are asking the question if they can donate tissues and organs and undergo tissue and organ transplantation.

Muslim scholars and jurists are only now beginning to come to grips with the medical practice of tissue and organ donation and transplantation. They continue to debate the matter in their quest for a resolution. The central question they seek to address is whether tissue and organ donation and transplantation are permissible or not in Islam. As the debates continue, Muslim scholars and jurists remain divided and no consensus exists regarding the permissibility or impermissibility of tissue and organ donation and transplantation in Islam.

Two principal positions exist on the question of whether tissue and organ donation and transplantation are permissible or not in Islam. Before explaining these positions in some detail, two points need to be made here. One is that during the era of the "Islamic Golden Age", different Muslim powers tried to bring about and preserve a greater Islamic unity by encouraging a greater level of cooperation between different Muslim sects and mosque communities divided by doctrine, theology, and practice and established Islamic ecumenism - the ummah, that is the idea of a single people. Islam then existed as a community state under the central authority of the caliphate (Islamic state) operating as a central governing system designed to cater for all its citizens in all spheres of life, although the caliphate was not an ideal socio-political system. Under the caliphate law, education, health, the military, social services, economy, judiciary, and the bureaucracy were intertwined. The state leadership established the pattern for the organisation and administration of the state activities and Islam was the source of state theology, ideology, identity, unity, and solidarity. Muslim empires such as the Ottoman (1299-1922), Safavid (1501-1736), and Mughal (1526-1857) who operated autonomously and sometimes were hostile towards each other were not perfect central governing systems but nevertheless had some semblance of central authority and uniformity (Esposito 2000). This is apparently not the case today. Contemporary Muslim populations are vastly diverse and their societies largely operate under the principles of secularism than under the shari'ah (Islamic law) (Lapidus 2014). In contemporary Muslim countries, there are huge variations in the implementation of Islamic law and the application of Qur'anic instructions and in many instances even an absence of reliance on Islamic law and religious texts can be noted and the religion rarely, if ever, plays an important role in the government, legal system, and social organisation of society (Nasr 2003). The decision-making machinery is diverse and inconsistent and Muslims do not have a real sense of ummah (Lapidus 2014).

Second is that in the absence of a legitimate and universally recognised established central authority, who speaks for Islam in the modern world is an unresolved question. Different Islamic institutions, organisations, muftis (plural-Muslim legal experts who have the authority to give rulings on religious matters), and sheikhs (plural-Muslim religious leaders and scholars) in different parts of the world claim to represent Islam and all Muslims, but how much legitimacy they really hold is highly questionable. In light of this fact, the discourse about tissue and organ donation and transplantation in Islam has become extremely technical and varied and consequently more than one position now exists on the matter. The subject of tissue and organ donation and transplantation is a highly contested one with diametrically opposite positions in existence today.

One group of scholars and jurists, mainly from the Middle East and from the Sunnibased Shafi'i school of jurisprudence and Shia sects (Jaffer and Alibhai 2008), have been claimed to give priority to living over spirituality and take an anthropocentric stance on the issue, generally favouring tissue and organ donation and transplantation. Proof of this can be found in the actions, for example, of the Supreme Council of the Ulama in Riyadh, Saudi Arabia in 1982 when it approved organ harvest and transplantation under medically necessary conditions (Report of the Senior Ulama Commission 1982, p. 46) and when the International Islamic Fiqh Academy of Jeddah (IIFA), under the directions of the Saudi Government in 1988, officially sanctioned organ transplantation (Ali and Maravia 2020). 
The other group comprise scholars and jurists from the subcontinent where around a third of the world's Muslim population live. These scholars and jurists argue that spirituality takes priority over living and hold a theocentric view declaring that tissue and organ donation and transplantation are not permissible in Islam. They rely on the Islamic view that the body is a "gift" from God and human beings do not own their bodies; there is no ownership over human bodies only custodianship (Aramesh 2009). The anti-tissue and anti-organ donation and transplantation position is aptly captured in the following fatwa (edict): "None is owner of his life and parts of the body, therefore neither can he sell it nor can gift to anyone. Such dealings are wrong and invalid" (Darul Ifta 2020, Fatwa: $1138 / 982=$ B /1429).

Although the Qur'an and hadiths are silent on the issue of tissue and organ donation and transplantation, Muslim scholars and jurists still rely on these sources to deliberate on the matter. These sources are still resourceful for them. They use these sources to explain related concepts and abstract topics, as well as employing legal sources or jurisprudential tools known as ijtihad (analogical deduction) to finally determine whether tissue and organ donation and transplantation are permissible or not in Islam. Muslim scholars and jurists from both camps, for deliberative purposes, use a combination of sources such as the Qur'an, hadiths, and various Islamic principles to develop their argument in favour or against tissue and organ donation and transplantation.

In the current literature on tissue and organ donation and transplantation in Islam, a large body of scholars and researchers often assert that the majority of Muslim scholars and jurists have arrived at the conclusion that tissue and organ donation and transplantation by living donors and from cadaveric bodies are permitted. This is problematic. The concern with such an assertion is two-fold. One is that the literature downplays the significance of the anti-tissue and anti-organ donation and transplantation perspective. Muslim scholars and jurists with this view make some solid cases for their position and they cannot be overlooked or simply diminished. Second, the literature does not question the philosophical unpinning, theological subjectivity, ethno-parochial partiality, and methodological inadequacy of Muslim scholars and jurists who support tissue and organ donation and transplantation. The discussions and debates concerning the permissibility or impermissibility of tissue and organ donation and transplantation need to be predicated on sound systematic analysis of Islamic scriptures and shari'ah, and the arguments must be developed adequately and objectively with a deep grounding in methodological soundness, precision, and proficiency.

An authoritative response to how Islam deals with and manages tissue and organ donation and transplantation is very much in a formative phase. More robust intellectual and scholarly discussions and debates are needed, and balanced and objective arguments must be presented. Tissue and organ donation and transplantation need to be examined and understood using Islamic theological knowledge, Islamic scriptures, legal and jurisprudential principles, and social scientific approaches in an attempt to dispel many myths and misunderstandings surrounding the issue in Islam.

This Special Issue aimed to do precisely that; freshly explore the scholarship on the debates regarding tissue and organ donation and transplantation in Islam. It not only describes the prevailing works and judgments made by Muslim scholars and jurists but also, and perhaps even more importantly, critiques them by putting their ontological and epistemological methodologies, theological rationales, and legal and jurisprudential principles under scrutiny. To this end, a collection of six research papers were gathered which explored from differing scholarly vantage points various issues surrounding tissue and organ donation and transplantation in Islam. Diverse in their approaches and analyses, what brings all six papers together in this Special Issue is the fact that they all work within the larger question of permissibility/impermissibility of tissue and organ donation and transplantation in Islam. In the paper entitled Applicability of Islamic Methodology Concerning Novel Issues to the Organ Transplantation in Religious Scholars' Contemporary Discourse, the author surveys the works of some leading scholars in the field who have studied the various 
religious viewpoints based on different schools of thought in Sunni Islam about tissue and organ donation and transplantation in Islam. The paper with the title A Review of the Rulings by Muslim Jurists on Assisted Reproductive Technology and Reproductive Tissue Transplantation looks at assisted reproductive technology in reproductive medicine in the context of tissue and organ donation and transplantation in Islam. There are complex religious, legal, moral, and ethical concerns surrounding tissue and organ donation and transplantation in Islam and the author uses the legal frameworks of ijtihad (independent judgment) and al-maqaasid al-shar'iyyah (the higher objectives of Divine decree) to assesses the Sunni juristic rulings pertaining specifically to the question of permissibility of assisted reproductive technology within the larger framework of tissue and organ donation and transplantation in Islam. In the paper entitled Organ Donation in Islam: A Search for a Broader Quranic Perspective, the author examines the Quranic verses cited by various scholars in their attempt to justify the permissibility of tissue and organ donation and transplantation in Islam. Data were collected from 36 studies which relied on Quranic verses to justify the permissibility of tissue and organ donation and transplantation. The author found that this approach made little effort to examine the verses using specific methodologies in the science of the Quran. The authors of Are Online Fatwas Credible? A Critical Analysis of Fifty Fatwas on Organ Donation and Transplantation examine the growing digitisation of religious understanding in the cyber world, in particular, the religious rulings pertaining to the question of permissibility or impermissibility of tissue and organ donation and transplantation in Islam. They assess the diversity and complexity of 50 online fatwas on tissue and organ donation and transplantation from various fatwa organisations, government bodies, and councils across 16 linguistically, ethnically, socio-culturally, and theologically different countries and argue that state appointed and controlled religious authorities who have no autonomy lack credibility in their fatwas. In the paper entitled Islamic Perspectives on Organ Transplantation: A Continuous Debate, the author examines in depth the two key perspectives on the questions of permissibility and impermissibility of tissue and organ donation and transplantation in Islam and highlights that further robust academic, theological, and sociological debates and research are needed to adequately address the questions. The author in the paper entitled A Gift of Generosity-An Explanation of Organ and Tissue Donation and Transplantation for Muslim Audiences explores the virtues of tissue and organ donation and transplantation in any end-of-life discussions. The premise of this work is that should individuals opt for tissue and organ donation or tissue and organ transplantation or both, then they must do so with full and proper understanding of the process through which organs become diseased and the reasons and methods of their replacements.

Funding: This research received no external funding.

Conflicts of Interest: The author declares no conflict of interest.

\section{References}

Al-Bar, Mohammed, and Hassan Chamsi-Pasha. 2015. Contemporary Bioethics: Islamic Perspective. New York: Springer. Ali, Mansur, and Usman Maravia. 2020. Seven Faces of a Fatwa: Organ Transplantation and Islam. Religions 11: 99. [CrossRef]

Aramesh, Kiarash. 2009. The Ownership of Human Body: An Islamic Perspective. Journal of Medical Ethics and History of Medicine 2: $1-4$.

Darul Ifta. 2020. Fatwa: 1138/982=B/1429. India: Darul Uloom Deoband, Available online: http://www.darulifta-deoband.com/home/ en/Halal--Haram/4578 (accessed on 12 December 2021).

Esposito, John. 2000. Oxford History of Islam. Oxford: Oxford University Press.

Hamilton, David. 2012. A History of Organ Transplantation: Ancient Legends to Modern Practice. Pittsburgh: University of Pittsburgh Press.

Jaffer, Iqbal, and Shabbir Alibhai. 2008. The Permissibility of Organ Donation, End-of-life Care, and Autopsy in Shiite Islam: A Case Study. In Muslim Medical Ethics: From Theory to Practice. Edited by Jonathan Brockopp and Thomas Eich. Columbia: The University of South Carolina Press, pp. 167-81.

Kee, Howard. 1986. Medicine, Miracle and Magic in New Testament Times. Cambridge: Cambridge University Press.

Lapidus, Ira. 2014. A History of Islamic Societies, 3rd ed. Cambridge: Cambridge University Press.

Nasr, Seyyed. 2003. Islam: Religion, History and Civilization. New York: HarperCollins Publishers. 
Peer, Lyndon. 1955. Transplantation of Tissues. Baltimore: William \& Wilkins.

Report of the Senior Ulama Commission. 1982. Report of the Senior Ulama Commission, Decision No. 99. Dated 06-11-1402. In Directory of the Regulations of Organ Transplantation in the Kingdom of Saudi Arabia. Jeddah: Saudi Center for Organ Transplantation.

Schlich, Thomas. 2010. The Origins of Organ Transplantation: Surgery and Laboratory Science, 1880-1930. New York: University of Rochester Press.

Seghers, Michel, and Jacob Longacre. 1964. Paul Bert and His Animal Grafts. Plastic and Reconstructive Surgery 33: 178-86. [CrossRef] [PubMed] 